\title{
Digenean parasites of the Family Lecithodendriidae (Luhe, 1901) Odhner, 1901 infecting the frog Hoplobatrachus tigerinus (Anura: Dicroglossidae) of the Western Ghats, Wayanad Region, India
}

\section{Keloth Shinad and Puthanpurayil Kandambeth Prasadan*}

Ecological Parasitology and Tropical Biodiversity Laboratory. Department of Zoology. Kannur University. Mananthavady Campus. Wayanad - 670645. Kerala. India. Email: prasadanpk@kannuruniv.ac.in.

\begin{abstract}
Three species of digenean parasites, Pleurogenoides euphlycti, P. wayanadensis and Meharorchis ranarum of the frog Hoplobatrachus tigerinus (Anura, Dicroglossidae) from the Wayanad Region of the South Western Ghats are reported in this paper. Multiple infections were also recorded during the study. Prevalence of infection of $P$. euphlycti, $P$. wayanadensis and M. ranarum were $15.15 \%, 9.09 \%$ and $12.12 \%$, respectively, and the intensity of infection were 5.2, 7.3 and 8, and the mean abundance were $0.78,0.66$ and 0.96 , respectively. Mean abundance is an indication of the dispersion of parasites among hosts. The mean abundance and the intensity were at the maximum level in M. ranarum infection and that of prevalence of infection was at the maximum level in of $P$. euphlycti infection.
\end{abstract}

Keywords: Digenean parasites; Frog; Hoplobatrachus tigerinus; Western Ghats; Prevalence.
Received

March 31, 2019

Accepted

August 30, 2019

Released

August 31, 2019

Full Text Article

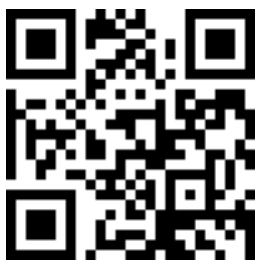

D 0000-0002-3876-9697 Keloth Shinad

D 0000-0001-7228-8435

Puthanpurayil

Kandambeth Prasadan 


\section{Introduction}

Amphibians, particularly anurans, harbour a variety of adult and larval trematodes involving freshwater gastropods as first intermediate hosts in their life-cycles (Duda and Verma, 1996). The trematode fauna of amphibians of India has been the subject of numerous investigations, including those by Mehra and Negi (1926a, b; 1928), Bhalerao (1926, 1936a, b, c; 1937), Srivastava (1933a, b; 1934a, b), Pande (1937), Chauhan (1954), Gupta and Agrawal (1966, 1967), Pandey (1968, 1969a, b, 1981), Gupta, (1970, 1977), Mukherjee and Ghosh (1970, 1972), Singh (1977) Janardanan et al. (1987), Janardanan and Prasadan (1991), Brinesh and Janardanan (2014) and Shinad and Prasadan (2017a, b, 2018a, b, c, d). Singh (1977) made the first contribution to the trematode fauna of amphibians in Kerala. Later Janardanan et al. (1987) recorded Pleurogenoides ovatus, Rao, 1977 from Rana tigrina (Hoplobatracus tigerinus) and later Janardanan and Prasadan (1991) elucidated its life cycle. The life cycle of a new species, P. malampuzhaensis was established by Brinesh and Janardanan (2014). Recently four new species of digenetic trematodes from amphibian hosts were reported from the Western Ghats by Shinad and Prasadan (2017a, b; 2018a).

$H$. tigerinus (Daudin, 1803) is a large frog, generally semi-aquatic in habit and probably the largest frog seen in India. They live in the fringes along rivers, reservoirs and marshes, inundated paddy fields and large ponds with floating vegetation. It is widely distributed throughout the low to moderate elevations in Nepal, Bhutan, western and central Myanmar through Bangladesh and India to northern Pakistan and south to the Western Ghats (Frost, 2014). Despite its common occurrence in different types of freshwater bodies, the parasite fauna had not been a subject of any in-depth study.
During our studies on the digenean parasites of frogs of the Western Ghats, Wayanad region an analysis was made on the species composition of digenean parasites of $H$. tigerinus.

This paper deals with the digenean parasites found in H. tigerinus of the Western Ghats, Wayanad region with their prevalence, intensity of infection and mean abundance.

\section{Materials and methods}

The study was carried out in the Wayanad region of the Western Ghats (latitudes $11^{\circ} 27^{\prime}$ and $15^{\circ} 58^{\prime}$ North and $75^{\circ} 47^{\prime}$ and $70^{\circ} 27^{\prime}$ East longitude). Western Ghats is a treasure trove of biological diversity in India and is considered one of the "hottest hotspots" of biodiversity because of its very rich fauna \& flora and the highest level of endemism. Prevalence, intensity of infection and mean abundance were measured following Bush et al. (1997).

Thirty three specimens of $H$. tigerinus collected during the period from January 2016 to January 2019 from various water bodies using sweep hand net were brought to the laboratory, maintained in cement cisterns and fed them occasionally with insects.

The specimens were narcotized with chloroform, dissected, their skin were removed, and the muscle tissues were macerated to detect the presence of metacercariae. Internal organs were also dissected out from each frog, placed in separate Petri dishes containing 0.75\% saline, macerated and examined under the stereozoom microscope. Adults, when present, were carefully removed, transferred to $0.75 \%$ saline in separate watch glasses and studied under Nikon ECLIPSE Ni-U phase contrast research microscope without supravital staining or after staining with neutral red. Permanent slides of adult parasites were prepared after fixing them in 5\% formalin under slight cover glass pressure and staining with acetocarmine, 
following the procedure outlined by Cantwell (1981). Specimens were measured using the Nikon NIS Elements Imaging software. All measurements are in micrometers $(\mu \mathrm{m})$, as range followed by mean in parentheses.

Illustrations were made using the Nikon Y-IDT drawing tube attached to the Nikon ECLIPSE Ni-U microscope and the details were added free hand from observations made on live specimens. Photographs were taken with a Nikon YTV55 camera.

\section{Results}

Three species of digenetic trematodes, $P$. euphlycti, $P$. wayanadensis and $M$. ranarum were found infecting the duodenum of the frog $H$. tigerinus (Table 1; Figures 1 to 3)).

Collection localities: Ellumandam, Kannur University Campus Mananthavady, Karakkuni, Karappuzha, Panamaram, Peechangode, Pulpally, Pyngatri, Thalappuzha Engineering College and Valliyoorkavu Wayanad District. Period of collection: January 2016 to January 2019.

Table 1. Digenean parasites with their prevalence, intensity of infection and mean abundance.

\begin{tabular}{|c|c|c|c|}
\hline Name of the parasite & $\begin{array}{c}\text { Prevalence of } \\
\text { infection }\end{array}$ & $\begin{array}{c}\text { Intensity of } \\
\text { infection }\end{array}$ & Mean abundance \\
\hline Pleurogenoides euphlycti & $\begin{array}{c}5 \text { out of } 33 \text { frogs } \\
(15.15 \%)\end{array}$ & $\begin{array}{c}26 \text { from } 5 \text { infected } \\
\text { frogs (5.2) }\end{array}$ & $\begin{array}{c}26 \text { in } 33 \text { frogs } \\
(0.78)\end{array}$ \\
\hline Pleurogenoides & $\begin{array}{c}3 \text { out of } 33 \text { frogs } \\
(9.09 \%)\end{array}$ & $\begin{array}{c}22 \text { from } 3 \text { infected } \\
\text { frogs (7.3) }\end{array}$ & $\begin{array}{c}22 \text { in } 33 \text { frogs } \\
(0.66)\end{array}$ \\
\hline wayanadensis & $\begin{array}{c}4 \text { out of } 33 \text { frogs } \\
(12.12 \%)\end{array}$ & $\begin{array}{c}32 \text { from } 4 \text { infected } \\
\text { frogs (8) }\end{array}$ & $\begin{array}{c}32 \text { in } 33 \text { frogs } \\
(0.96)\end{array}$ \\
\hline
\end{tabular}

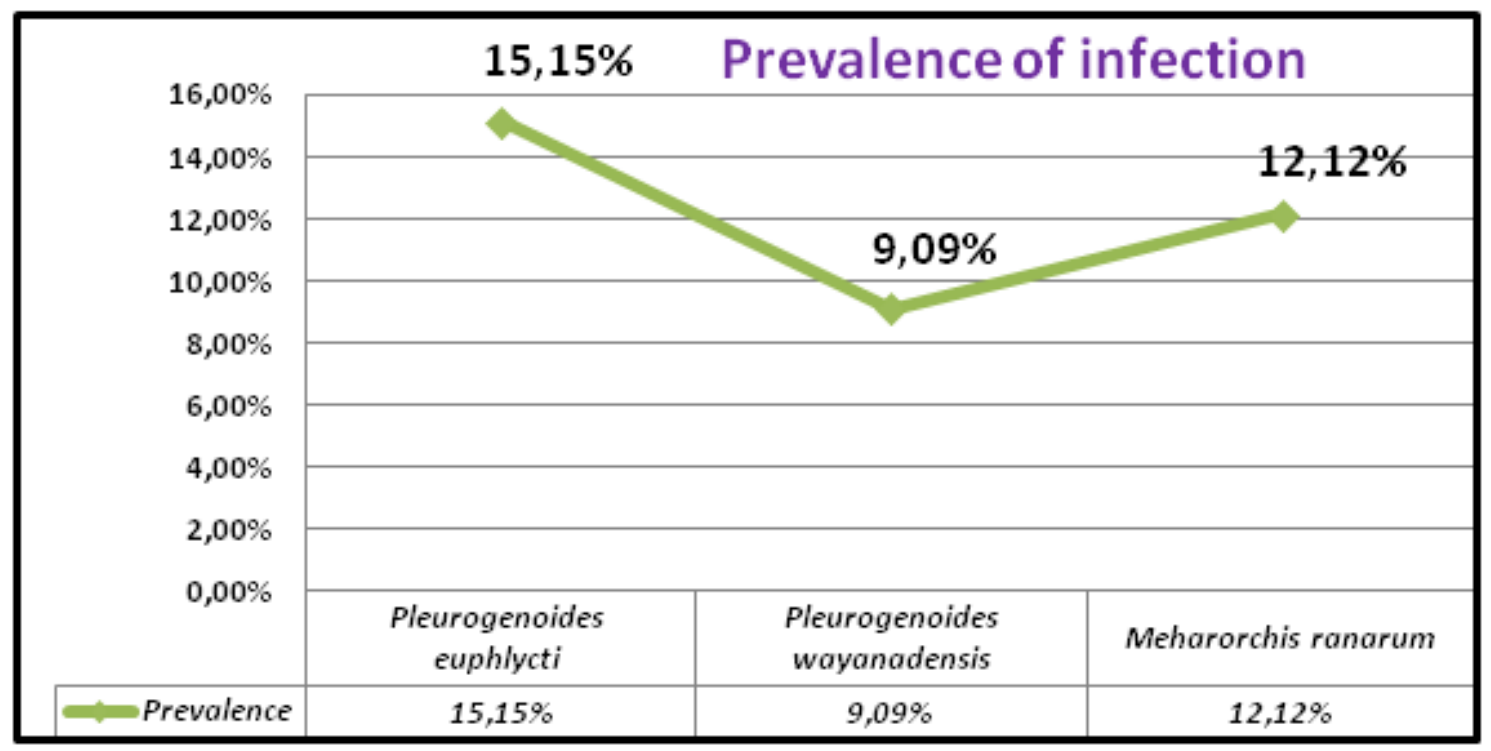

Figure 1. Digenean parasites with their prevalence of infection. 


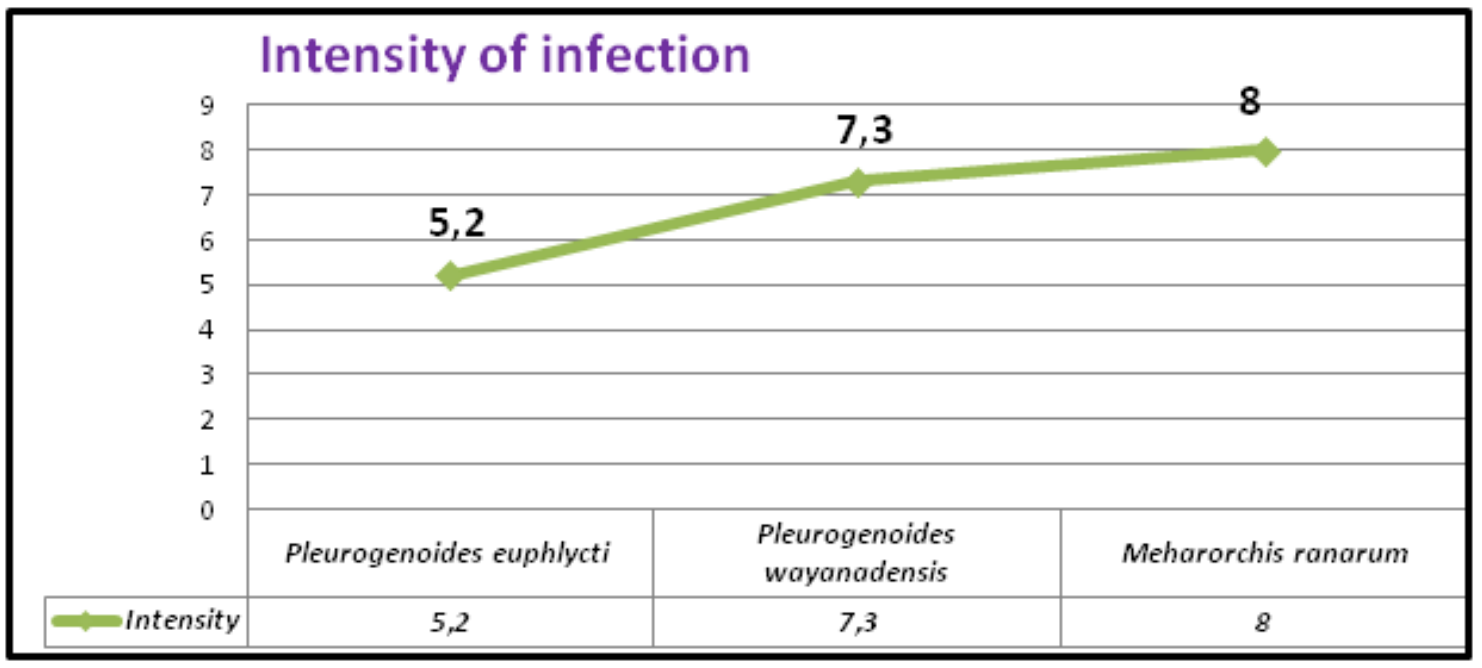

Figure 2. Digenean parasites with their intensity of infection.

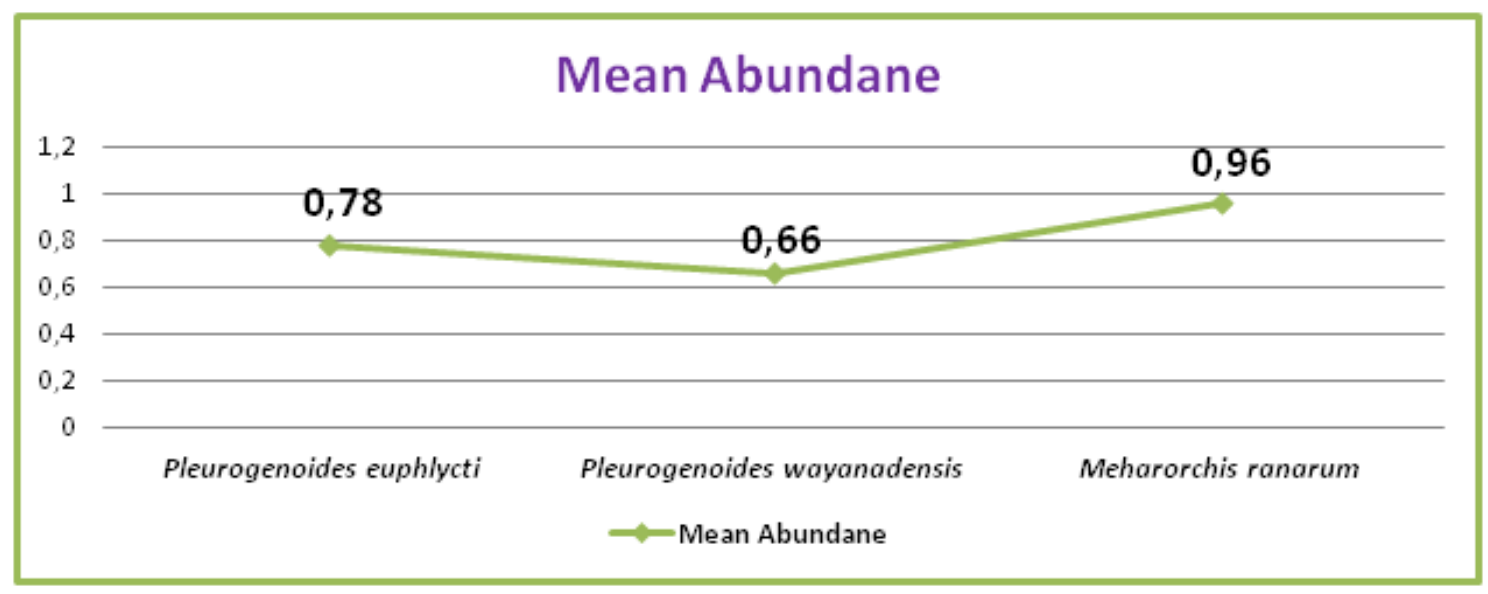

Figure 3. Digenean parasites with their mean abundance

Family: Lecithodendriidae (Luhe, 1901) Odhner, 1901 1901

\section{Genus Pleurogenoides Luhe,}

P. euphlycti Shinad and Prasadan, 2018 (Figure 4)

Based on the length of the intestinal caeca Travassos (1921) established the genus Pleurogenoides of the Family Pleurogenidae Looss, 1899 to accommodate those species of the genus Pleurogenes Looss, 1896, and considered $P$. tener as its type species. On the basis of the length of intestinal caeca and position of genital pore, Mehra and Negi dropped the genus Pleurogenoides into two sub genera, $\quad P$.(Pleurogenes) and P. (Telogonella). Srivastava (1934a) also dropped the genus Pleurogenoides and transferred the species under it to Pleurogenes. But Macy (1936) retained the genus Pleurogenoides and the same were accepted by Kaw (1943) and Mukherjee and Ghosh (1970). Of the 32 species of Pleurogenoides recorded worldwide from amphibians, 16 species, viz - P. gastroporus (Luhe, 1901) Travassos, 1921, P. sphaericus (Klein, 1905) Travassos, 1921, P. gastroporus var. equalis Mehra and Negi, 1926, P. medians var. equalis Mehra and Negi, 1926, P. prayagi Mehra and Negi, 1926, 
P. solus (Johnston, 1912) Travassos, 1930, P. orientalis Srivastava, 1934, P. bufonis Kaw, 1943, P. sitapurii (Srivastava, 1934) Kaw, 1943, P. sawanensis Gupta, 1954, P. amritsarensis Gupta and Chopra, 1984, P. ovatus Rao, 1977, P. jamshedpuransis Husnain and Sahay, 1988, P. ranchiensis Dan and Sahay, 1991, P. sahranensis Chakrabarti et al., 2011 and P. malampuzhensis Brinesh and Janardanan, 2014 were recorded from India. Life cycles of two species of Pleurogenoides, $P$. ovatus and P. malampuzhaensis have been elucidated from Kerala (Janardanan and Prasadan, 1991; Brinesh and Janardanan, 2014) respectively. Recently three new species of Pleurogenoides, P. cyanophlycti, $P$. euphlycti and P. wayanadensis were described by Shinad and Prasadan (2017b, 2018a) from Euphlyctis cyanophlyctis of the Wayanad region of the Western Ghats.

Remarks: The species is characterized by slightly ovoid body with a slightly ovoid anterior and broadly round posterior ends. Its body is covered with minute, backwardly directed spines which are closely set at the anterior and posterior regions and sparsely distributed in the central region. Its oral sucker is sub-terminal, almost circular and almost equal to or slightly larger than ventral sucker. It has a circular and post-equatorial ventral sucker. Its mouth is sub-terminal with a muscular pharynx. Oesophagus is short or absent. It has a baseball racket shaped intestinal caeca ending at the level of ovary and left testis. Its two testes are equal sized, spherical, equatorial or post-equatorial, symmetrical and placed one on either side of ventral sucker in the lateral body margins. It has a claviform cirrus sac which extends from the equator to genital pore, at the left body margin near the level of oral sucker; it encloses bipartite seminal vesicle, well developed pars-prostatica, long and narrow ejaculatory duct and an un-spinose cirrus. Its ovary is small, spherical or ovoid, lies close to the level of right caecum, above the level of ventral sucker and right testis. Uterus is post-acetabular and winding, mostly in the hind body. Its eggs are ovoid, operculate and have well developed vitellaria, present only at the posterior region of pharynx.

Five out of $33 \mathrm{H}$. tigerinus were infected with $P$. euphlycti and the prevalence of infection is $15.15 \%$. Twenty six $P$. euphlycti were recovered from five frogs so the intensity of infection is 5.2 and 26 P. euphlycti were recovered from a total of 33 frogs so the mean abundance is 0.78 (Table 1 ).

Multiple infections were observed in few frogs with $P$. wayanadensis and M. ranarum.
Collection

Panamaram, Wayanad District. localities:
A1

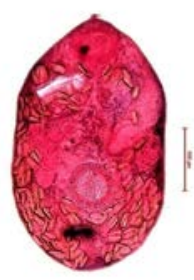

A2

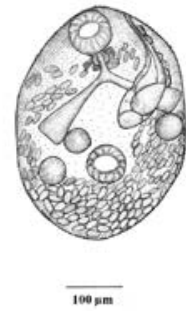

Figure 4. P. euphlycti (A1 and A2).

\section{$P$. wayanadensis Shinad and Prasadan, 2018 (Figure 5) \\ Remarks: The species has an} ovoid body, with a slightly ovoid anterior and broadly round posterior ends. Body is covered with minute spines which are backwardly directed and that are closely set throughout the body. It has a circular, sub-terminal oral sucker larger than ventral sucker. Its ventral sucker is circular and equatorially placed. Its mouth is sub-terminal and pharynx is muscular and ovoid. Its oesophagus is short or absent. Its caeca reach up to the 
middle of testes and below ventral sucker. It has two, spherical testes, equatorial or post-equatorial, symmetrical and placed one on either side near the posterior margin of ventral sucker in the lateral body margins. It has claviform cirrus sac, extends from the posterior margin of ventral sucker to genital pore, at the left body margin near the mid level of oral sucker and it encloses bipartite seminal vesicle, well developed pars-prostatica, long and narrow ejaculatory duct and an unspinose cirrus. It has a spherical ovary, at the zone of ventral sucker, in between ventral sucker and right caecum. Uterus is post - acetabular and winding, mostly in the hind body. Eggs are ovoid, operculate and vitellaria are absent.

Three out of $33 \mathrm{H}$. tigerinus were infected with $P$. wayanadensis and the prevalence of infection is $9.09 \%$. Twenty two $P$. wayanadensis were recovered from three frogs and the intensity of infection is 7.3 and 22 P. wayanadensis were recovered from a total of 33 frogs so the mean abundance is 0.66 (Table 1 ).

Multiple infection was observed in a few frogs with $P$. euphlycti and $M$. ranarum.

Collection

localities:

Panamaram, Wayanad District.
B1

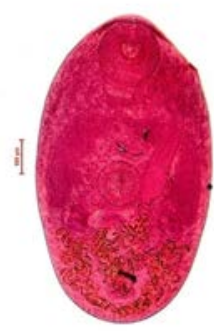

B2

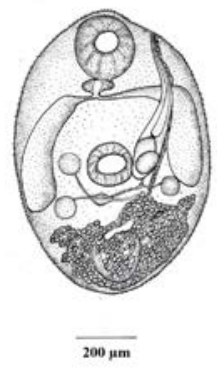

Figure 5. P. wayanadensis (B1 and B2).

\section{Family: Lecithodendriidae (Luhe, 1901) Odhner, 1901 \\ Genus Mehraorchis Srivastava, 1934}

Mehraorchis ranarum
Srivastava, 1934 (Figure 6)
The genus Mehraorchis was erected by Srivastava (1934) with $M$. ranarum from Rana cyanophlyctis as its type species. So far three species, $M$. tigrinarum Gupta, 1954, M. jainiformis Bharadwaj, 1961 and M. cyanophlicticus Karyakarte, 1973 have been added to the genus from Indian amphibians. They were encysted in hepatic system or free in intestine of amphibians and reptiles. Gupta and Agarwal (1966) synonymised $M$. tigrinarum with $M$. ranarum. The first report of $M$. ranarum from Kerala was made by Singh from the intestine of Rana tigrina in Punalur in 1977. The second report of this parasite was made by Muraleedharan, 1989 from the body cavity and ileum of the two frog hosts $R$. Limnocharis and $R$. tigrina in Chundale, Wayanad district.

Remarks: They are large virgulate digeneans. The species is characterized by ovoid body covered with prominent spines which are numerous at the anterior region and gradually decrease posteriorly. It has a terminal to sub terminal oral sucker and an equatorial to pre-equatorial, ventral sucker at. It has sub terminal mouth, globular pharynx, long oesophagus and intestinal caeca that, terminates near the posterior end of body. It has two symmetrical testes at the anterior third. It has a muscular and claviform cirrus sac, which extends from the intestinal bifurcation to the genital pore, at the left body margin near the mid level of oral sucker and it encloses well developed seminal vesicle, pars-prostatica and ejaculatory duct. It has an oval shaped ovary placed intercaecal in the ventral sucker zone between ventral sucker and right testis. Its uterus is post ovarian and filling mostly in the posterior half of the body. Eggs are ovoid and non operculate. Its vitellaria are well developed, lateral 
and flower like, extending from the level of pharynx to the posterior margin of ovary, on each side.

Four out of $33 \mathrm{H}$. tigerinus were infected with $M$. ranarum so the prevalence of infection is $12.12 \%$. Thirty two $M$. ranarum were recovered from four frogs and the intensity of infection is 8 and $32 M$. ranarum were recovered from a total of 33 frogs so the mean abundance is 0.96 (Table 1 ).

Multiple infections were observed in a few frogs with $P$. wayanadensis and P. euphlycti.

\section{Collection}

localities:

Ellumandam, Karappuzha and Panamaram Wayanad District.
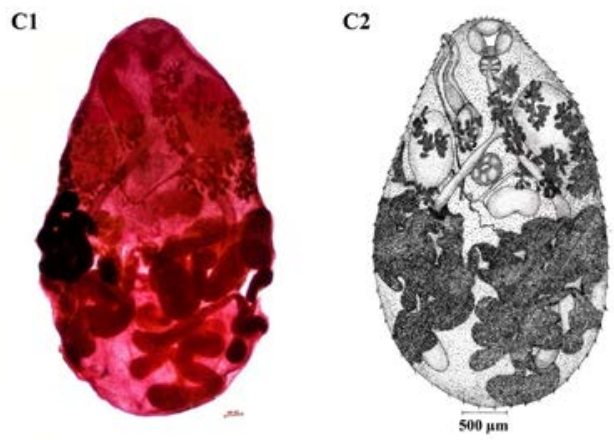

Figure 6. M. ranarum (C1 and C2).

\section{Acknowledgements}

The authors are grateful to the Kerala State Council for Science, Technology and Environment (KSCSTE), Government of Kerala for providing financial assistance in the form of a major research project (SRS/220/2015/ KSCSTE) to carry out this study. The permission accorded by the Department of Forest and Wildlife, Government of Kerala (Order No WL10-63909/2016) for collecting frogs from the Wayanad forest region is also gratefully acknowledged. The authors are indebted to Prof. K. P. Janardanan for critically going through the manuscript.
All applicable international, national, and/or institutional guidelines for the care and use of animals were followed. All procedures performed in the study involving animals were in accordance with the ethical standards of the institution or practice at which the study was conducted.

\section{Conflict of interest}

Authors declare that that there is no conflict of interest.

\section{References}

Bhalerao, G. D. On the trematodes of the digestive tract of a common Indian frog, Rana tigrina, with a description of Centrovitus pentadelphi n. g., n. sp. Parasitology, v. 18, p.154-159, 1926. https://doi.org/10.1017/ S0031182000005102

Bhalerao, G. D. Studies on the helminths of India. Trematoda I. Journal of Helminthology, v. 14 , no. 3, p. 163-180, 1936a. https://doi.org/10.1017/S0022149X 00003679

Bhalerao, G. D. Studies on the helminths of India. Trematoda II. Journal of Helminthology, v. 14 , no. 4, p.181-206, 1936b. https://doi.org/10.1017/S0022149X 00004089

Bhalerao, G. D. Studies on the helminths of India. Trematoda III. Journal of Helminthology, v. 14, no. 4, p. 207-228, 1936c. https://doi.org/10.1017/S0022149X 00004090

Bhalerao, G. D. Studies on the helminths of India. Trematoda IV. Journal of Helminthology, v. 15, no. 2, p. 97-124, 1937. https://doi.org/10.1017/S0022149X000307 53

Brinesh, R.; Janardanan, K. P. The life history of Pleurogenoides malampuzhensis sp. nov. (Digenea: Pleurogenidae) from amphibious and aquatic hosts in Kerala, India. Journal of Helminthology, v. 88, p. 230-236, 2014. https://doi.org/10.1017/S0022149X130000 84

Bush, A. O.; Lafferty, K. D.; Lotz, J. M.; Shostak, A. W. Parasitology meets ecology on its own 
terms: Margolis et al. revisited. Journal of Parasitology, v. 83, no. 4, p. 575-583, 1997.

Cantwell, G. E. Methods for invertebrates. In: Clark G. (Eds.). Staining procedures. Baltimore: Williams and Wilkins, 1981. p. 255-280.

Chakrabarti, S.; Anindita, G.; Venkataraman, K. On a new trematode parasite Pleurogenoides sahransis n. sp. (Lecithodendriidae: Pleurogeninae) from Rana cyanophlyctis of Sahran, Himachal Pradesh, India. Journal of Interacademicia, v. 15 , no. 4 , p. $610-615,2011$.

Chauhan, B. S. Studies on the trematode fauna of India. Part. IV. Subclass Digenea (Prosostomata) (A revision of Hemiuroidea from Indian Region). Records of Indian Museum, v. 51, p. 289-393, 1954.

Duda, P. L.; Verma, A. K. Role of gastropods in trematode transmission among amphibians: A numerical analysis. In: Koul, B. L. (Ed.). Advances in fish and wildlife ecology and biology. New Delhi 1: Daya Publishing House, 1996. p. 236-239.

Frost, D. R. Amphibian species of the world. Version 6.0. Electronic database, 2014. Available from: <http://research.amnh.org/ vz/herpetology/amphibia/>. Accessed on: Apr. 23, 2019.

Gupta, N. K. On Pleurogenes (Telogonella) swanensis $\mathrm{n}$. sp. parasitic in the intestine of Rana cyanophlictis with a discussion of the systematic position of the genus Pleurogenes Looss, 1896. Research Bulletin of Punjab University, v. 58, p. 143-148, 1954.

Gupta, N. K.; Chopra, R. On digenetic trematodes of amphibians from India. Part I. Research Bulletin of Punjab University, v. 35, p. 1-6, 1984.

Gupta, P. D. Fauna of Rajastan, India, Part 8. Trematoda. Records of the Zoological Survey of India, v. 62, p. 171-190, 1970.

Gupta, P. D. Studies on the genus Ganeoi Klein, 1905 (Trematoda. Lecithodendridae). Records of the Zoological Survey of India, v. 72, p. 281-290, 1977.

Gupta, S. P.; Agarwal, V. Two trematode parasites of Rana cyanophlictis from Udaipur (Rajastan). Proceedings of the National Academy of Sciences, India Section B: Biological Sciences, v. 36, p. 530-536, 1966.
Gupta, S. P.; Agrawal, V. On a new trematode, Halipegus udaipurensis n. sp. from Rana cyanophlyctis from Udaipur. Indian Journal of Helminthology, v. 19, p. 77-80, 1967.

Janardanan, K. P.; Prasadan, P. K. Studies on the life-cycle of Pleurogenoides ovatus Rao, 1977 (Trematoda: Pleurogenetinae). Journal of Helminthology, v. 65, no. 1, p. 43-50, 1991. https://doi.org/10.1017/S0022149X0 0010427

Janardanan, K. P.; Shanavas, K. R.; Usha, N. V. On the progenetic metacercaia of Pleurogenordes ovatus Rao, 1977 (Trematoda: Pleurogenetinae) from the freshwater crab, Paratelphusa hydrodromous (Herbst), with observation on its in vitro excystment. Zoologischer Anzeiger, v. 219, p. 313-320, 1987.

Karyakarte, P. P. Mehrorchis cyanophlicticus sp. n. (Trematoda: Lecithodendridae) from the frog Rana cyanophlyctis India. Marathwada University Journal of Science, v. 5, p. 225-228, 1973.

Kaw, B. L. Studies on the helminth parasites of Kashmir. Part II. On two new trematodes of the Sub-Family Pleurogenetinae Looss (1899) with a review of the genus Pleurogenes Looss (1896). Proceedings of the National Academy of Sciences, India Section B: Biological Sciences, v. 18, p. 97108, 1943.

Klein, W. Neue Distomen aus Rana hexadactyla. Zoologische Jahrbücher. Abteilung für Systematik, Geographie und Biologie der Tiere, v. 22, p. 1-22, 1905.

Looss, A. Weitere Beitrage zun Kenntniss der Trematoden-Fauna Aegyptens. Zoologische Jahrbücher. Abteilung für Systematik, Geographie und Biologie der Tiere, v. 12, p. 521-784, 1899.

Macy, R.W. A new genus and species of trematodes from the little brown bat, and a key to the genera of Pleurogenetinae. Proceedings of the United States National Museum, v. 83, p. 321-324, 1936.

Mehra, H. R.; Negi, P. S. On a new trematode Tremiorchis ranarum nov.gen.spec. from the common Indian frog Rana tigrina. Parasitology, v. 18, p. 168-181, 1926a.

Mehra, H. R.; Negi, P. S. The trematode parasites of Rana tigrina of the Family Pleurogenetinae Luhe. Proceedings of the 
Indian Science Congress, v. 13, p. 185-186, 1926b.

Mehra, H. R.; Negi, P. S. Trematode parasites of the Pleurogenetinae from Rana tigrina with a revision and synopsis of the sub family. Allah Univiversity Study, v. 4, p. 63118, 1928.

Mukherjee, R. P.; Ghosh, R. K. Studies on some amphibian trematodes from Uttar Pradesh and West Bengal. (Part I). Indian Journal Helminthology, v. 22, p. 61-78, 1970.

Mukherjee, R. P.; Ghosh, R. K. Studies on some amphibian trematodes from West Bengal and Maharashtra (Part II). Records of the Zoological Survey of India, v. 66, p. 273276, 1972.

Muraleedharan, P. Studies of the digenetic trematodes of the amphibians in Kerala. MPhil dissertation, 1989.

Pande, B. P. On some digenetic trematodes from Rana cyanophlyctis of Kumaon hills. Proceedings of the Indian Academy of Sciences - Section B, v. 6, p. 109-120, 1937. https://doi.org/10.1007/BF03051116

Pandey, K. C. A redisription of Halipegus mehransis Srivastava 1933 from the common Indian frog, Rana cyanophlictis Schneider. Indian Journal Helminthology, v. 21, p. 109-114, 1969b.

Pandey, K. C. On a new trematode Diplodiscus chauhani n. sp. from the common Indian frog, Rana cyanophlictis Schneider. Indian Journal Helminthology, v. 29, p. 203-206, 1969a.

Pandey, K. C.; Agarwal, N. Further remarks on the genus Tremiorchis Mehra and Negi, 1925. Proceedings of the Indian Academy of Sciences Animal Sciences, v. 90, p. 567-570, 1981.

Pandey, K. C.; Chakrabarti, K. K. On a new trematode Diplodiscus lali n. sp. from the common Indian frog Rana tigrina Daud. Ceylon Journal of Science (Biological Sciences), v. 8, p. 38-41, 1968.

Rao, R. On a new species of Pleurogenoides Travassos, 1971 (Lecithodendriidae, Odhner, 1910) and P. sitapurii Srivastava, 1934 from frogs in Hyderabad. Rivista di Parasitologia, v. 38, no. 1, p. 23-29, 1977.

Shinad, K.; Prasadan, P. K. Description of Diplodiscus cyanophlycti n. sp. (Digenea: Paramphistomidae) and prevalence and intensity of two other digeneans infecting the water skipper, Euphlyctis cyanophlyctis from the Western Ghats, India. International Journal of Fisheries and Aquatic Studies, v. 5, no. 6, Part D, p. 259-263, 2017a.

Shinad, K.; Prasadan, P. K. Two new species of Pleurogenoides (Luhe, 1901) Travassos, 1921 (Digenea: Pleurogenidae) infecting two species of frogs of the Western Ghats, India. Journal of Parasitic Diseases, v. 42, p. 130136, 2018a. https://doi.org/10.1007/ s12639-018-0978-y

Shinad, K.; Prasadan, P. K. First record of Encyclometra colubrimurorum (Rudolphi, 1819) Dollfus, 1929 (Digenea: Plagiorchiidae) metacercariae from a tadpole and an adult frog of the Western Ghats, India. International Journal of Fisheries and Aquatic Studies, v. 6, p. 135-139, 2018b.

Shinad, K.; Prasadan, P. K. Prevalence, intensity and mean abundance of Digenean parasites of the water skipper, Euphlyctis cyanophlyctis (Anura, Dicroglossidae) of the South Western Ghats. International Journal of Fisheries and Aquatic Studies, v. 6, no. 6, p. 278-284, 2018c.

Shinad, K.; Prasadan, P. K. Digenean parasites of the water skipper Euphlyctis cyanophlyctis (Schneider, 1799) (Anura: Dicroglossidae) of the South Western Ghats, India. Brazilian Journal of Biological Sciences, v. 5, no. 11, p. 747-756, 2018d. https://doi.org/ 10.21472/bjbs.051112

Singh, M.S. Studies on the amphibian trematodes from Tamil Nadu and Kerala. Records of the Zoological Survey of India, v. 72, p. 291-294, 1977.

Srivastava, H. D. On new trematodes of frogs and fishes of the United Provinces, India. Part. I. Distomes of the family Hemiuridae from North Indian fishes and frogs with a systematic discussions of the Family Halipegidae and the genera Vitellotrema guberlet and Genarchopsis ozaki. Bulletin of the Academy of Sciences of the United Provinces of Agra and Oudh, v. 3, p. 1-60, 1933a.

Srivastava, H. D. On new trematodes of frogs and fishes of the United Provinces, India. Part II. Three new trematodes of the Subfamily Pleurogenetinae (Family Lecithodendriidae) from Rana cyanophlyctis of Oudh. Bulletin of the Academy of Sciences of the United 
Provinces of Agra and Oudh, v. 3, p. 41-60, 1933b.

Srivastava, H. D. On new trematodes of frogs and fishes of the United Provinces, India. Part III. On a new genus Mehraorchis and two new species of Pleurogenes (Pleurogenetinae) with a systematic discussion and revision of the Family Lecithodendriidae. Bulletin of the Academy of Sciences of the United Provinces of Agra and Oudh, v. 3, p. 239256, 1934a.

Srivastava, H. D. On new trematodes of frogs and fishes of the United Provinces, India. Part. IV. The occurrence and seasonal incidence of infection of certain trematodes of the above hosts. Bulletin of the Academy of Sciences of the United Provinces of Agra and Oudh, v. 4, p. 113-119, 1934b.

\author{
Travassos, L. Contribuição para o \\ conhecimento da fauna helmintológica \\ brasileira. XII. Sobre espécies brasileiras da \\ Sub-Família Brachycoelinae. Arquivo da \\ Escola Superior de Agricultura e Medicina \\ Veterinária, v. 5, no. 1/2, p. 73-79, 1921.
}

